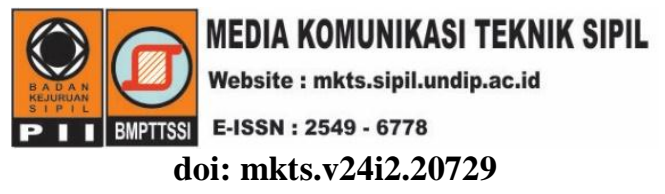

\title{
Turbulence Characteristic of Flow Near Laboratory Experiment Groin Fields
}

\author{
Pradipta Nandi Wardhana \\ Faculty of Civil Engineering and Planning, Universitas Islam Indonesia, Yogyakarta \\ ${ }^{*}$ pradipta.nw@uii.ac.id
}

Received: 8 Oktober 2018 Revised: 26 November 2018 Accepted: 28 November 2018

\begin{abstract}
Groin is hydraulic structure utilized to protect riverbank from erosion. Groin will shift away flow. Area just downstream of groin structure will be occupied by low velocity flow hence there will be sediment deposition. Turbulence mechanism between primary flow region and groin field having important role in sediment exchange needs to be investigated. Instantaneous flow measurement was conducted in order to investigate turbulence relation between series groin under various groin spacing. Laboratory experiment employed turbulence flow having Reynolds number range between 31,935-32,500 and Froude number range between 0.051-0.053. A MicroADV 16-MHz was used to measure 3D instantaneous velocity. The experiment findings expressed that Reynolds stress involving vertical velocity $-\rho \overline{u_{f} w_{f}} / \rho u_{*}^{2}$ and $-\rho \overline{v_{f} w_{f}} / \rho u_{*}^{2}$ did not show any specific distributions except at the lowest measurement elevation, while Reynolds stress $-\rho \overline{u_{f} v_{f}} / \rho u_{*}^{2}$ showed specific distributions. Turbulence value difference between groin field and primary flow region at upstream of the groin field was significant. As the area was getting downstream, area containing high turbulence was wider. This work indicated that bed shear stress value $\tau_{b} / \tau_{b, a}$ tended to grow at downstream area of groin field. High difference bed shear stress value $\tau_{b} / \tau_{b, a}$ between primary flow region and groin field seized second groin field and third groin field.
\end{abstract}

Keywords: Groin, ADV, reynolds stress, bed shear stress

\begin{abstract}
Abstrak
Groin adalah struktur hidraulik yang digunakan untuk melindungi tepi sungai dari erosi. Struktur groin akan mengelakkan arus sungai menjauh dari tepi sungai. Arus air dengan kecepatan rendah akan mengisi area di sebelah hilir groin sehingga akan mengakibatkan sedimentasi. Mekanisme turbulensi antara area aliran utama dan area groin perlu diinvestigasi untuk memahami proses tranpor sedimen antara kedua area tersebut. Pengukuran kecepatan sesaat dilakukan untuk mengetahui karakter turbulensi pada groin berseri yang dipengaruhi oleh variasi jarak antar groin. Penelitian laboratorium dilakukan pada aliran dengan angka Reynolds 31.935-32.500 dan angka Froude 0,051-0,053. Kecepatan sesaat tiga dimensi diukur dengan menggunakan MicroADV 16-MH. Hasil penelitian menunjukkan tegangan Reynolds yang dipengaruhi oleh kecepatan vertikal $-\rho \overline{u_{f} w_{f}} / \rho u_{*}^{2}$ dan $-\rho \overline{v_{f} w_{f}} / \rho u_{*}^{2}$ tidak menunjukkan distribusi spesifik kecuali pada elevasi pengukuran paling rendah. Tegangan Reynold $-\rho \overline{u_{f} v_{f}} / \rho u_{*}^{2}$ menunjukkan distribusi yang spesifik. Perbedaan nilai turbulensi antara area groin dan area aliran utama sangat signifikan terutama di area groin sebelah hulu. Hasil penelitian menunjukkan bahwa semakin ke hilir, area dengan nilai turbulensi besar akan semakin lebar. Tegangan dasar saluran $\tau_{b} / \tau_{b, a}$ juga akan semakin besar di area groin sebelah hilir. Perbedaan tegangan dasar saluran $\tau_{b} / \tau_{b, a}$ yang besar antara area groin dan area aliran utama terdapat pada area groin kedua dan ketiga.
\end{abstract}

Kata kunci: Groin, ADV, tegangan reynolds, tegangan dasar saluran

\section{Introduction}

Groin is hydraulic structure that transverses river in order to maintain river depth as well as to protect riverbank. The mechanism is groin will deflect flow away from riverbank hence the area downstream of groin will be occupied by low velocity. Groin is applied in river with various 
parameters such as groin angle, material, shape, spacing, and height. Figure 1 shows schema of groin and parameter used in this work.

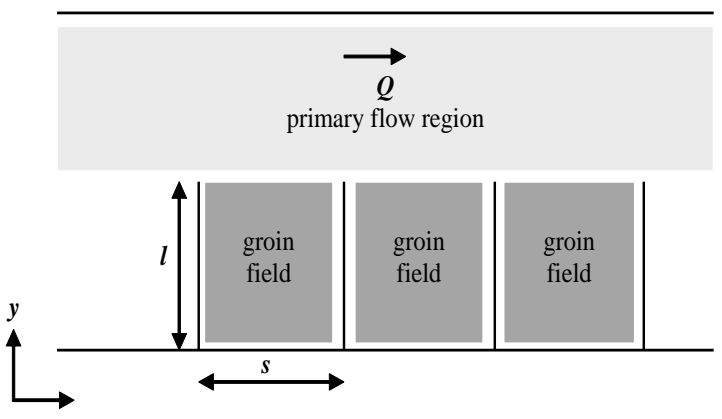

Figure 1. Groin

Spacing between groins is one of parameter influencing groin performance. The effectiveness of groin performance can rise if groin spacing decreases. More details, if spacing between groins too far, water current will flows to riverbank before reach zone influenced by downstream groin. On the other hand, if spacing between groins are too narrow, application of groin will be less efficient therefore cost needed to build groin structure will more expensive (Klingemann et al., 1984).

Kuhnle et al (2008) investigated flow around single trapezoidal shaped submerged groin over a fixed flat bed. Research was conducted by velocity measurement at laboratory and numerical simulation. Overall, research revealed similar result regarding velocities parameter for both physical and numerical simulation. The research also found that numerical model and physical model obtain similar results regarding shear stress distribution that could trigger scour zone located just downstream groin structure at recirculation zone.

Kuhnle \& Alonso (2013) measured threedimensional instantaneous velocity over fixed scoured bed caused by single submerged groin. The study showed that local scour occurrence was caused by strong lateral flows located at upstream and downstream of groin. Moreover, bed shear stress occurred in the scour hole rose or was stable with time.

Dehghani et al (2013) compared scoured depth between single laboratory L-head groin and straight groin. In this study, scour depth influenced by L-head groin was less than scour depth produced by straight groin. In addition, maximum local scour located at upstream direction was deeper than maximum local scour at downstream side.
Kadota et al (2010) analyzed local flow around several groin shape (I-type groin, T-type groin, and L-type groin) under emerged and submerged flow condition. Overall, this study found high turbulence located at groin tips and strong vortex at downstream direction. Furthermore, L=shaped groin produced great coherent pattern change.

Alauddin \& Tsujimoto (2013) performed investigation regarding effect of groin permeability and groin alignment toward local scour development. Research results revealed that impermeable groin produced the deepest local scour and also groin alignment reduced development of local scour depth.

Duan (2009) carried out investigation of flow characteristic influenced by single groin. The research demonstrated flow separation and flow circulation located at just downstream of groin. Besides, turbulence intensity distribution rose as the flow passed groin.

Muto et al (2000) investigated flow in series of groin having spacing to length ratio of $s / l=1$. The research showed that there is big circular flow located in groin zone. Result of velocity measurement revealed that velocity at second and third groin field were higher than velocity at first groin field. Moreover, Reynold stress distribution had tendency to grow wider as the area is getting downstream.

Recently, there are few researches investigating flow characteristic influenced by series groin. Meanwhile, there are many applications of series groin structure at field to protect river banks. Thus, effectiveness of series groin application need to be investigated. Effectiveness of series groin installation can be measured based on sediment deposition at downstream of groin structure while flow turbulence has significant role toward sediment rate.

This study investigated flow turbulence that was influenced by series groin. The laboratory experiment compared influence of spacing to length ratio $(s / l)$ toward turbulence magnitude and turbulence distribution.

\section{Theoretical Consideration}

\section{Reynolds stress}

Shear stress caused by turbulence can be considered as flow moves through element area $d A$ as can be seen at Figure 2, while $v f$ is instantaneous perpendicular velocity toward $d A$, and $u f$ is 
velocity fluctuation at both side of the area $d A$. Positive velocity fluctuation $v f$ causes fluid moves to upper layer slower that will cause momentum transport rate at upper layers decreases. On the other hand, if velocity $v f$ has negative value, fluid will cross the area downward faster thus transport momentum rate at lower layer will increase. As consequence, value of $v f>0$, and $v f<0$ reduce transport momentum difference in layers below and above $d A$. Positive value of $u f$ is correspondence negative value of $v f$.

Below equation expresses mass of fluid moves through area $d A$ in a unit time.

$d M=\rho v_{f} d A$

The mass equation above is applied to momentum equation.

$d M=d M d U$

or

$d F=-\rho v_{f} d A u_{f}$

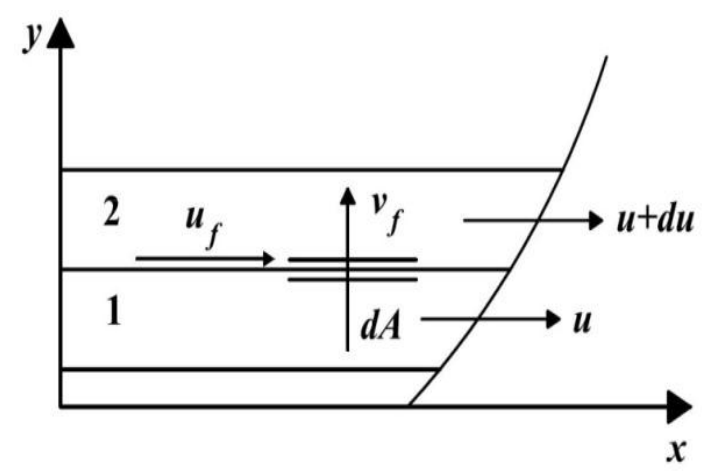

Figure 2. Momentum transfer in liquid flow

Shear stress value $\tau$ due to turbulence fluctuation is determined by dividing the momentum equation above with $d A$.

$\tau=-\frac{d F}{d A}=-\frac{\rho v \prime d A u \prime}{d A}$

or

$\tau=-\rho v^{\prime} u^{\prime}$

Shear stress given by equation above is known as Reynolds shear stress.

\section{Bed shear stress}

Dey \& Barbhuiya (2005) suggested mathematical equation below to calculate bed shear stress.

$\tau_{b}=\sqrt{\left(\tau_{b}^{x}\right)^{2}+\left(\tau_{b}^{y}\right)^{2}}$

where

$\tau_{\mathrm{b}}^{\mathrm{x}}=-\left.\rho\left(\overline{\mathrm{u}_{\mathrm{f}} \mathrm{W}_{\mathrm{f}}}+\overline{\mathrm{u}_{\mathrm{f}} \mathrm{v}_{\mathrm{f}}}\right)\right|_{\text {bed }}$ and

$\tau_{b}^{\mathrm{y}}=-\left.\rho\left(\overline{\mathrm{v}_{\mathrm{f}} \mathrm{W}_{\mathrm{f}}}+\overline{\mathrm{v}_{\mathrm{f}} \mathrm{u}_{\mathrm{f}}}\right)\right|_{\text {bed }}$

\section{Research Methods}

Laboratory experiment was conducted at Hydraulic Laboratory Universitas Gadjah Mada. Standard tilting flume was made from flexi glass which had dimension $1000 \mathrm{~cm}$ length, $30 \mathrm{~cm}$ width, and 50 $\mathrm{cm}$ height. The hydraulic experiment was conducted by using fixed bed flume. To simulate turbulence phenomenon, this work used laboratory experiment groin having $70 \mathrm{~cm}$ height, $15 \mathrm{~cm}$ length and $1.5 \mathrm{~cm}$ width. Flow running properties can be seen at Table 1. Figure 3 illustrates experiment scenario variations that the scenario is differentiated by changing groin distance of $30 \mathrm{~cm}$, $45 \mathrm{~cm}$, and $60 \mathrm{~cm}$.

MicroADV was utilized to obtain instantaneous velocity by employing principle of Doppler shift (Sontek, 2001). Acoustic Doppler Velocimeter (ADV) output had nine data consisting of three velocity values (one for each receiver), three signal strength values, or noise signal ratio (one for each receiver), and three correlation coefficient values (one for each receiver).

The main purpose of measurement was velocity parameter, whereas signal strength value and correlation value had role in accuracy and quality purposes. For turbulence flow measurement, SonTek (2001) stated that data obtained must have $70 \%$ correlation value and $15 \mathrm{SNR}$ value. The data acquisition would use $50 \mathrm{~Hz}$ sampling value. Each measurement point would be measured as long as 60 seconds.

\section{Result and Discussion}

Reynolds stress value and bed shear stress obtained at this work were normalized by shear velocity $u^{*}$ examined at approach flow. Below figures illustrated dimensionless Reynolds stress and bed shear stress distribution at XY plane and YZ plane.

Reynolds stress $-\rho \overline{u_{\mathrm{f}} \mathbf{w}_{\mathrm{f}}} / \rho \mathrm{u}_{*}^{2}$ and $-\rho \overline{\mathbf{v}_{\mathrm{f}} \mathbf{w}_{\mathrm{f}}} / \rho \mathrm{u}_{*}^{2}$

This work revealed that Reynolds stress distribution $-\rho \overline{u_{\mathrm{f}} \mathrm{W}_{\mathrm{f}}} / \rho \mathrm{u}_{*}^{2}$ and $-\rho \overline{\mathrm{v}_{\mathrm{f}} \mathrm{W}_{\mathrm{f}}} / \rho \mathrm{u}_{*}^{2}$ did not show specific distribution for all scenario. Furthermore, there were no significant difference of Reynolds stress magnitude between groin field and primary flow region. Figure 4 and 5 showed illustration of $\mathrm{YZ}$ plane distribution. It could be concluded that Reynolds stress value $-\rho \overline{u_{\mathrm{f}} \mathrm{W}_{\mathrm{f}}} / \rho u_{*}^{2}$ and $-\rho \overline{v_{f} W_{f}} / \rho u_{*}^{2}$ was smaller than Reynolds stress 
$-\rho \overline{\mathrm{u}_{\mathrm{f}} \mathrm{V}_{\mathrm{f}}} / \rho \mathrm{u}_{*}^{2}$ due to small value of vertical velocity compared velocity at horizontal direction.

Figure 6 and 7 depicted that at the lowest point, Reynolds stress located at primary flow region was slightly higher than Reynolds stress at groin field especially for $s / l=2$ scenario and $s / l=4$ scenario. Scenario $s / l=4$ also showed high Reynolds stress $-\rho \overline{u_{\mathrm{f}} \mathrm{W}_{\mathrm{f}}} / \rho \mathrm{u}_{*}^{2}$ but the Reynolds stress value of $-\rho \overline{\mathrm{v}_{\mathrm{f}} \mathrm{W}_{\mathrm{f}}} / \rho \mathrm{u}_{*}^{2}$ was low particullarly at the downstream area.

Table 1. Summary of laboratory experiment flow properties

\begin{tabular}{cccccccc}
\hline Run & Groin spacing $(\mathbf{c m})$ & $\boldsymbol{Q}(\mathbf{l} / \mathbf{s})$ & $\boldsymbol{h}(\mathbf{c m})$ & $\boldsymbol{S}$ & $\boldsymbol{F}$ & $\boldsymbol{R}$ & $u_{r}^{*}(\mathbf{c m} / \mathbf{s})$ \\
\hline$s / l 2$ & 30 & 5.1 & 21.75 & 0.0008 & 0.053 & 32,500 & 0.34 \\
$s / l 3$ & 45 & 5.1 & 22.20 & 0.0008 & 0.052 & 32,107 & 0.30 \\
$s / l 4$ & 60 & 5.1 & 22.40 & 0.0008 & 0.051 & 31,935 & 0.34 \\
\hline
\end{tabular}

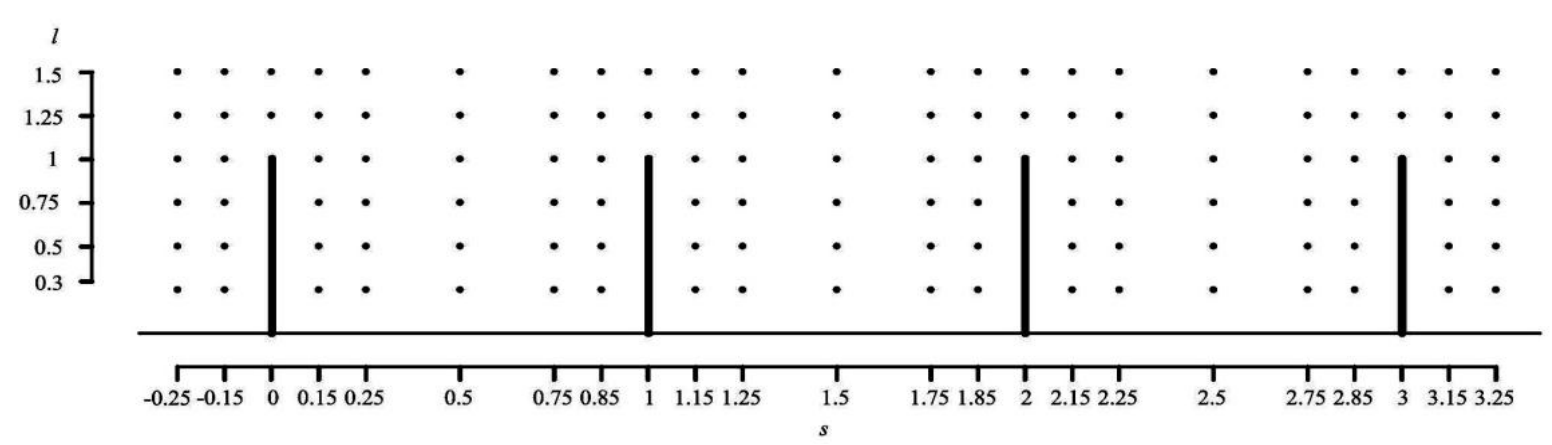

Figure 3. Illustration of velocity measurement position

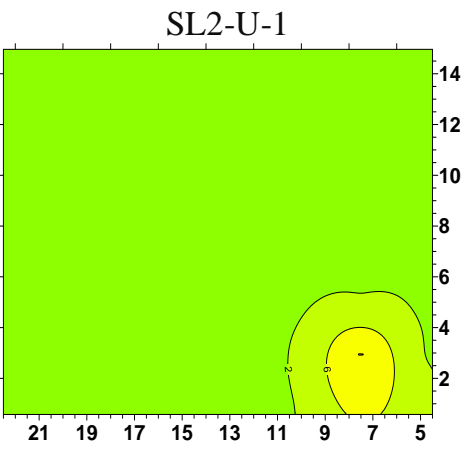

SL2-GF3-2

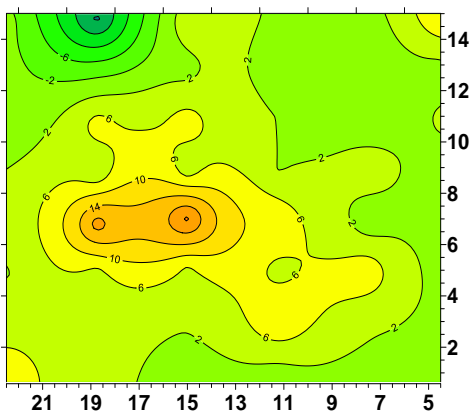

SL2-GF1-3

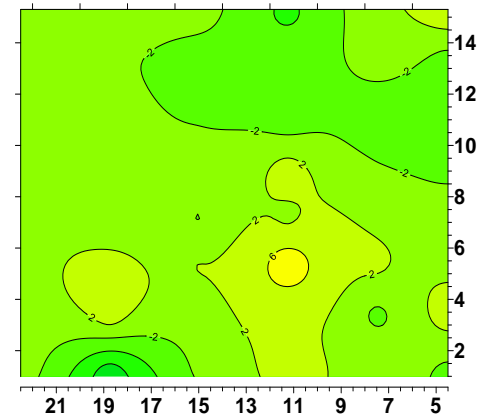

SL2-D-2

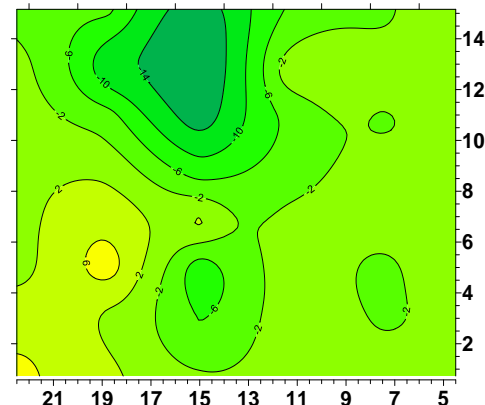

SL2-GF2-3

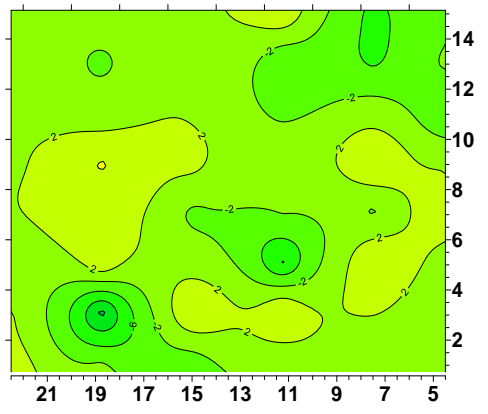

cross section location

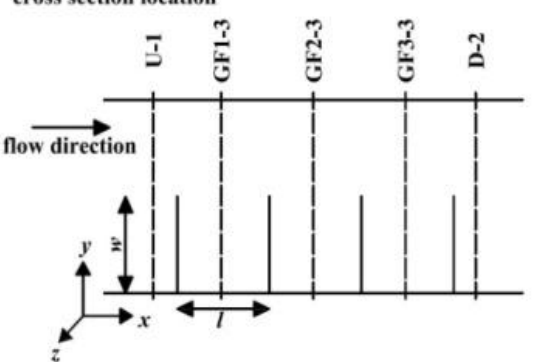

Figure 4. Reynolds stress $-\rho \overline{\mathrm{u}_{\mathrm{f}} \mathrm{W}_{\mathrm{f}}} / \rho \mathrm{u}_{*}^{2}$ at second groin field $(s / l=2$ ) 
SL2-U-1

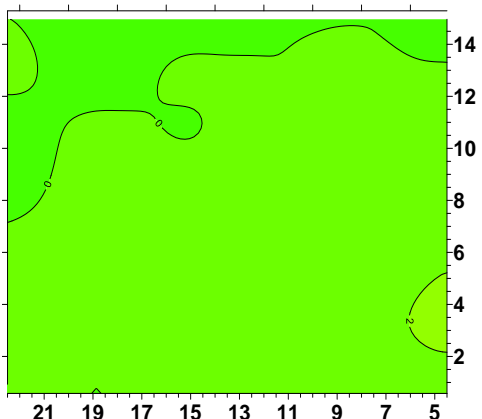

SL2-GF3-3

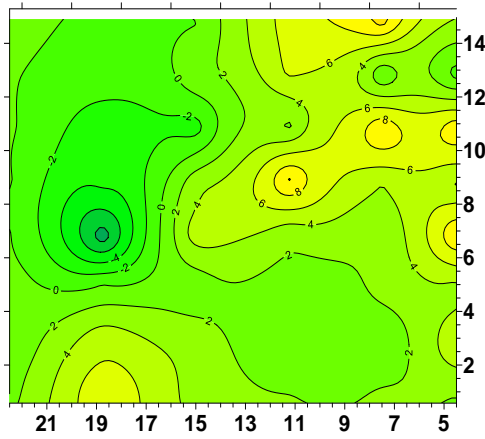

SL2-GF1-3

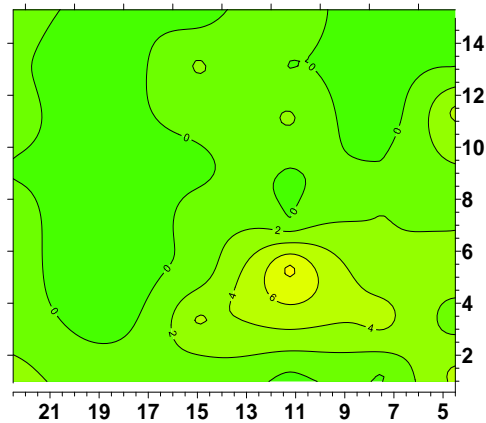

SL2-D-2

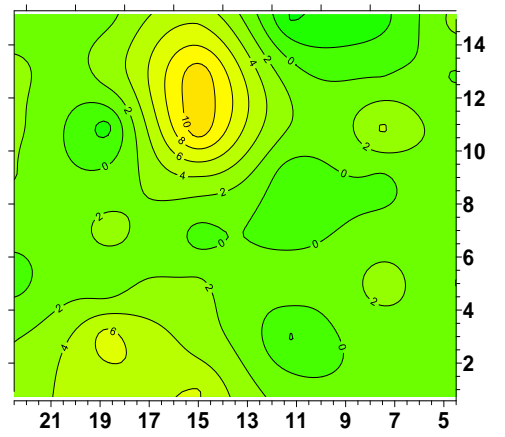

SL2-GF2-3

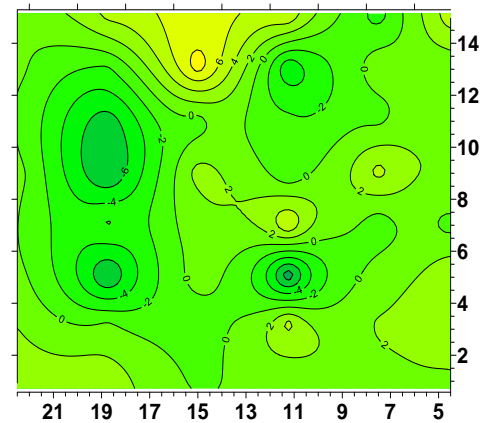

cross section location

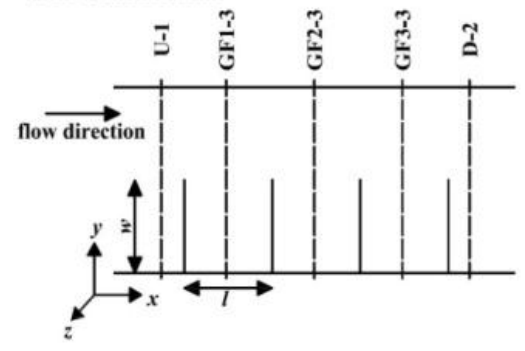

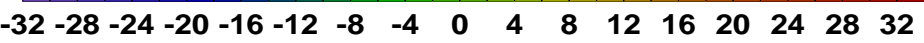

Figure 5. Reynolds stress $-\rho \overline{\mathrm{v}_{\mathrm{f}} \mathrm{W}_{\mathrm{f}}} / \rho \mathrm{u}_{*}^{2}$ at second groin field $(s / l=2)$

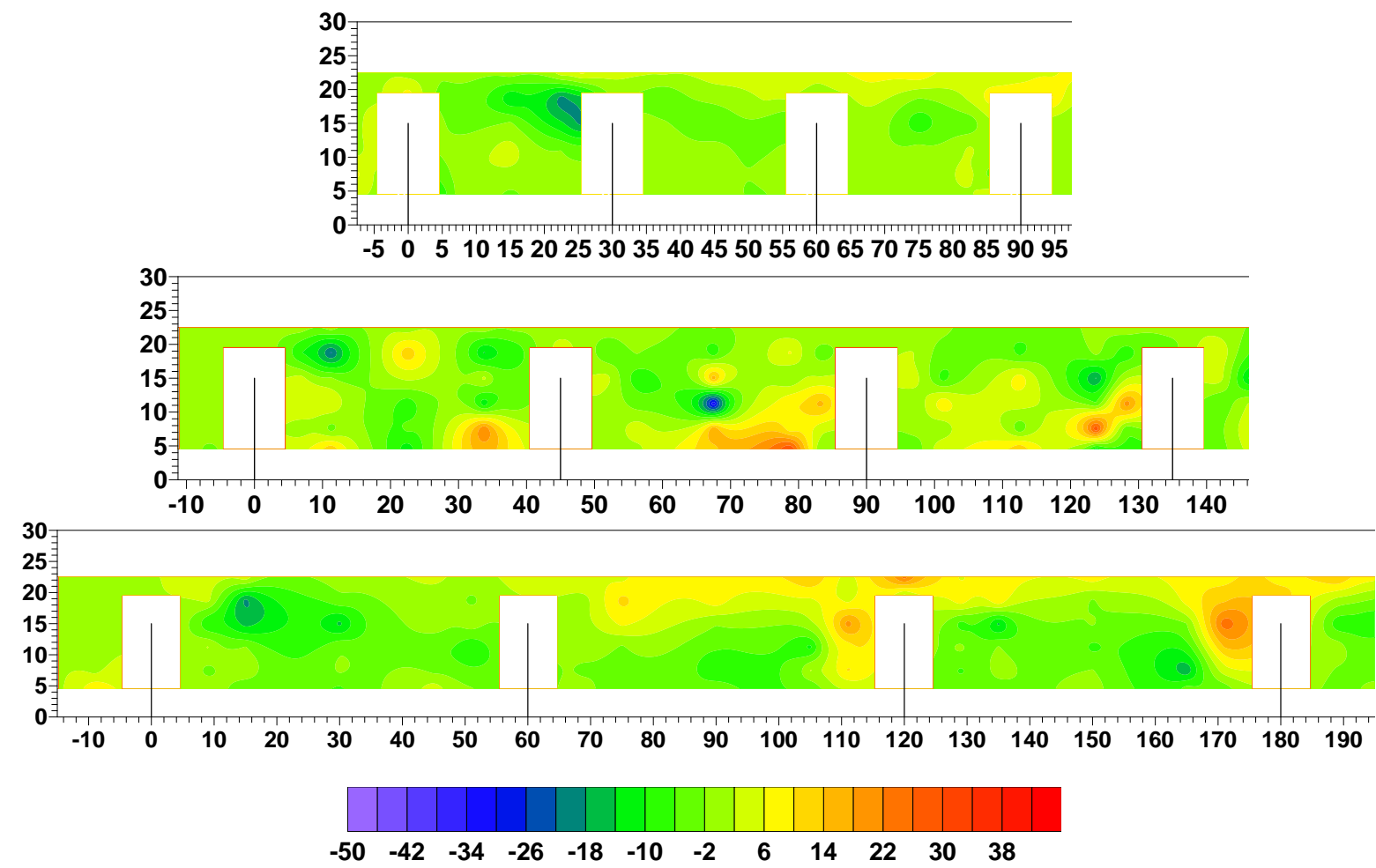

Figure 6. Reynolds stress $-\rho \overline{\mathrm{u}_{\mathrm{f}} \mathrm{W}_{\mathrm{f}}} / \rho u_{*}^{2}$ at $z / d=0.05$ for $s / l=2$ (top), $z / d=0.05$ for $s / l=3$ (middle), and $z / d=0.04$ for $s / l=4$ (bottom) 


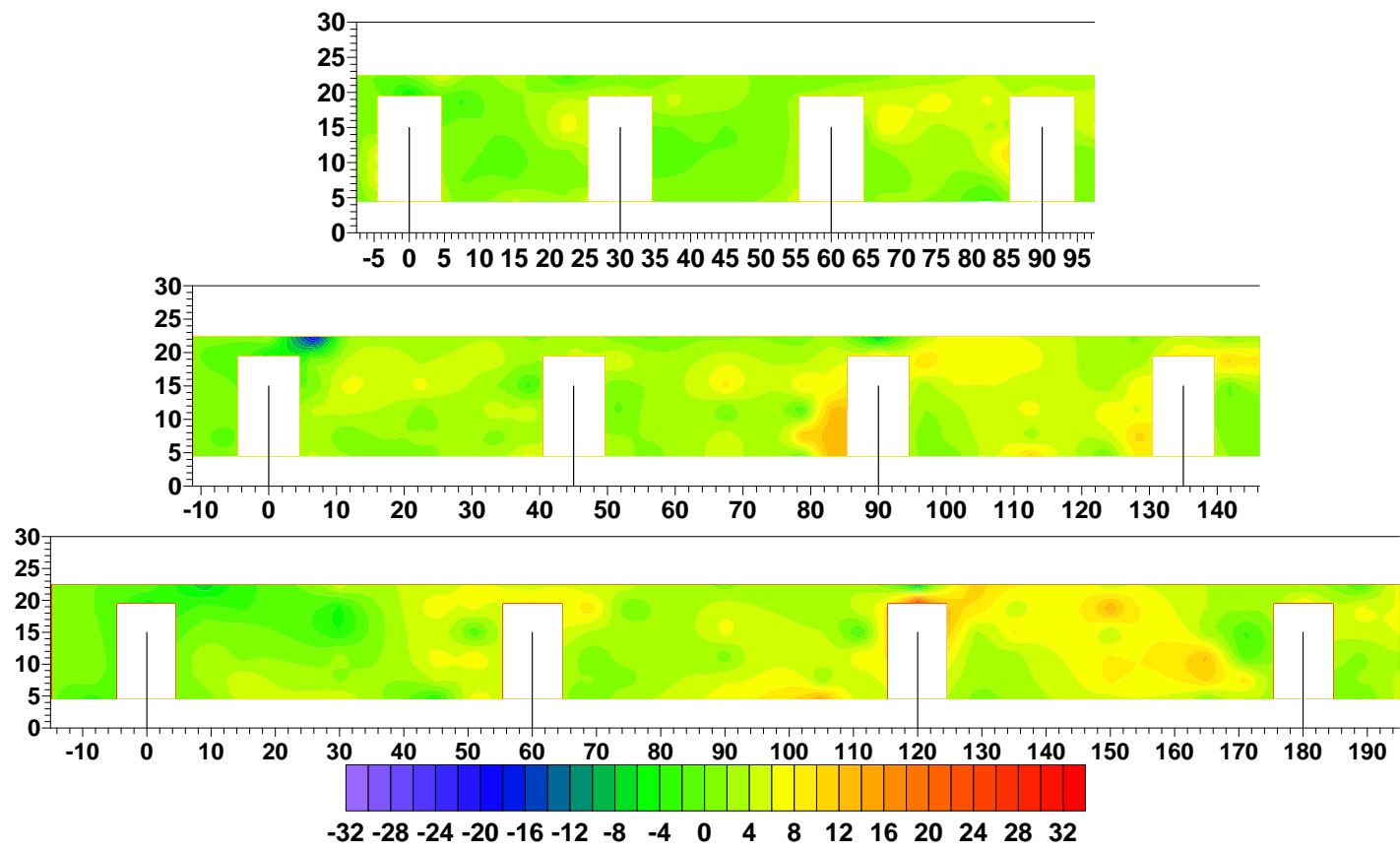

Figure 7. Reynolds stress $-\rho \overline{\mathrm{V}_{\mathrm{f}} \mathrm{W}_{\mathrm{f}}} / \rho \mathrm{u}_{*}^{2}$ at $z / d=0.05$ for $s / l=2$ (top), $z / d=0.05$ for $s / l=3$ (middle), and $z / d=0.04$ for $s / l=4$ (bottom)

\section{Reynolds stress $-\rho \overline{\mathbf{u}_{\mathrm{f}} \mathbf{v}_{\mathrm{f}}} / \rho \mathbf{u}_{*}^{2}$}

This work showed that high Reynolds stress value $-\rho \overline{\mathrm{u}_{\mathrm{f}} \mathrm{v}_{\mathrm{f}}} / \rho \mathrm{u}_{*}^{2}$ occupied primary flow region for all scenarios. Significant difference of $-\rho \overline{\mathrm{u}_{\mathrm{f}} \mathrm{V}_{\mathrm{f}}} / \rho \mathrm{u}_{*}^{2}$ value between groin field and primary flow region filled area at upstream of each groin field.

Figure 8, 9 and 10 showed that as further downstream of groin field, area inhibiting high stress tended to spread, moreover the big difference would shrink. Muto et al (2000) and Duan (2009) also found similar finding. Generally, magnitude of Reynolds stress $-\rho \overline{\mathrm{u}_{\mathrm{f}} \mathrm{v}_{\mathrm{f}}} / \rho \mathrm{u}_{*}^{2}$ obtained was different for each scenario. Reynold stress value $-\rho \overline{\mathrm{u}_{\mathrm{f}} \mathrm{v}_{\mathrm{f}}} / \rho \mathrm{u}_{*}^{2}$ for $s / l=2$ scenario was the lowest among all scenario. Furthermore, Figure 11 revealed that magnitude for $s / l=4$ was slightly higher than value for $s / l=3$. For scenario $s / l=4$, distribution of high Reynolds stress $-\rho \overline{\mathrm{u}_{\mathrm{f}} \mathrm{v}_{\mathrm{f}}} / \rho \mathrm{u}_{*}^{2}$ value was wider, and area containing high Reynolds stress shifted into groin field as further downstream. Scenario of $s / l=2$ showed constant Reynolds stress $-\rho \overline{\mathrm{u}_{\mathrm{f}} \mathrm{V}_{\mathrm{f}}} / \rho \mathrm{u}_{*}^{2}$ value along sequence groin fields. At initial cross section, all scenario revealed similar distribution, but as getting downstream $s / l=3$ and $s / l=4$ result tended to grow.
SL2-GF2-1

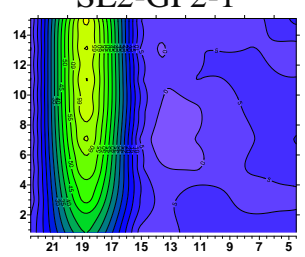

SL2-GF2-4

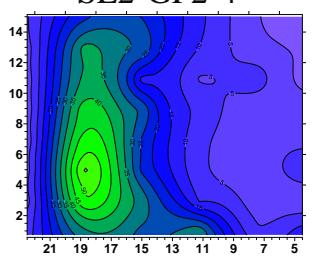

SL2-GF2-2

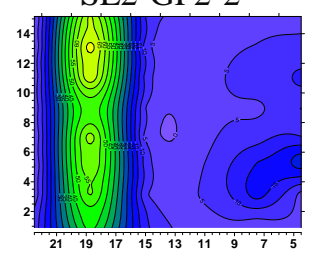

SL2-GF2-5

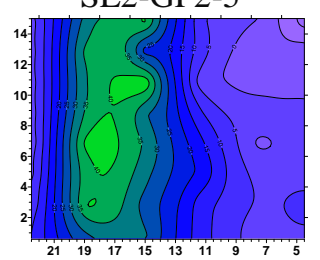

SL2-GF2-3

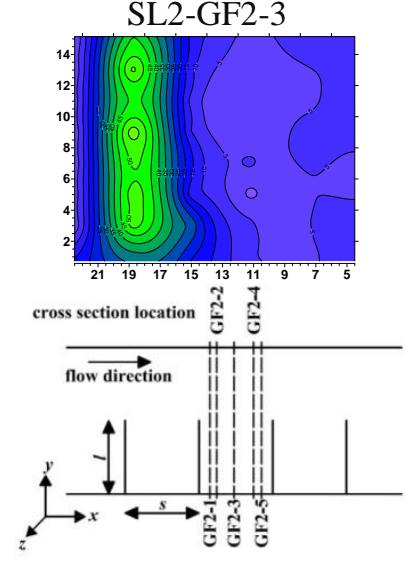

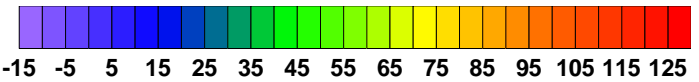

Figure 8. Reynolds stress $-\rho \overline{\mathrm{u}_{\mathrm{f}} \mathrm{V}_{\mathrm{f}}} / \rho u_{*}^{2}$ of second groin field ( $s / I=2$ ) 
SL3-U-1

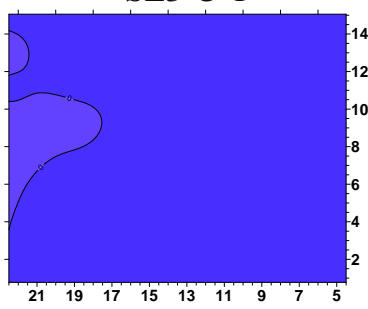

SL3-GF2-3

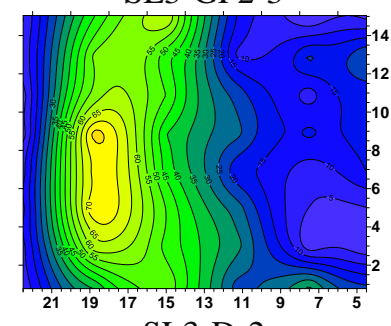

SL3-D-2

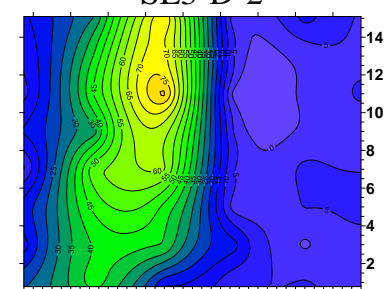

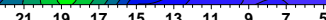

$\begin{array}{lllllllllllllll}-15 & -5 & 5 & 15 & 25 & 35 & 45 & 55 & 65 & 75 & 85 & 95 & 105 & 115 & 125\end{array}$

gure 9. Reynolds stress $-\rho \overline{\mathrm{u}_{\mathrm{f}} \mathrm{v}_{\mathrm{f}}} / \rho u_{*}^{2}$ of second groin field $(s / l=3$ )

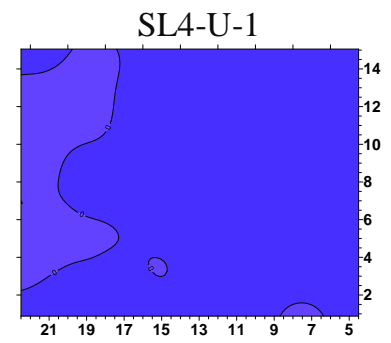

SL4-GF2-3

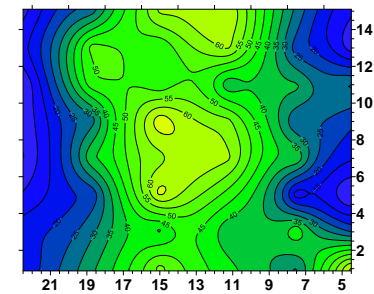

SL4-D-2

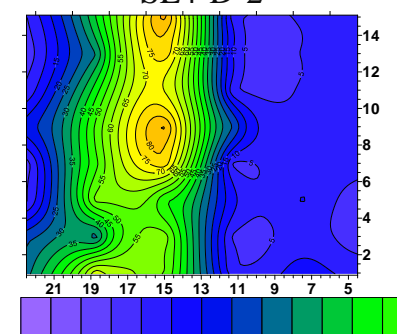

$\begin{array}{lllllllllllllll}-15 & -5 & 5 & 15 & 25 & 35 & 45 & 55 & 65 & 75 & 85 & 95 & 105 & 115 & 125\end{array}$

Figure 10. Reynolds stress $-\rho \overline{\mathrm{u}_{\mathrm{f}} \mathrm{v}_{\mathrm{f}}} / \rho \mathrm{u}_{*}^{2}$ of second groin field ( $s / l=4$ )
SL3-GF1-3

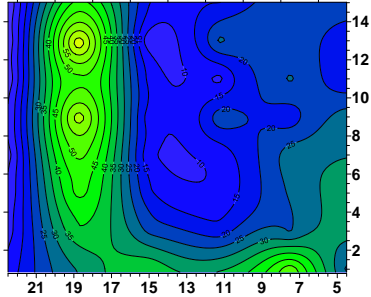

SL3-GF3-3
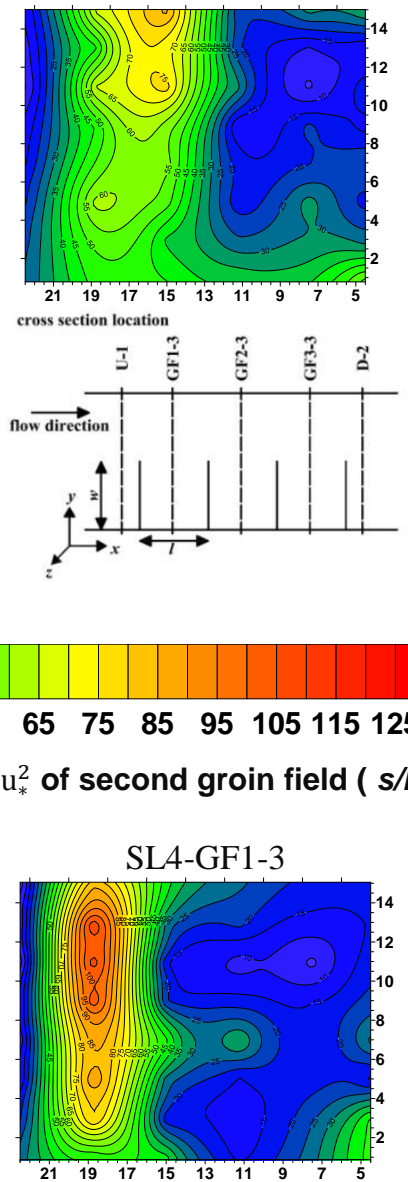

SL4-GF3-3
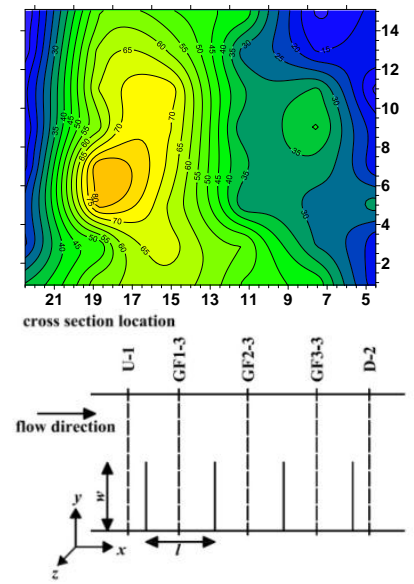

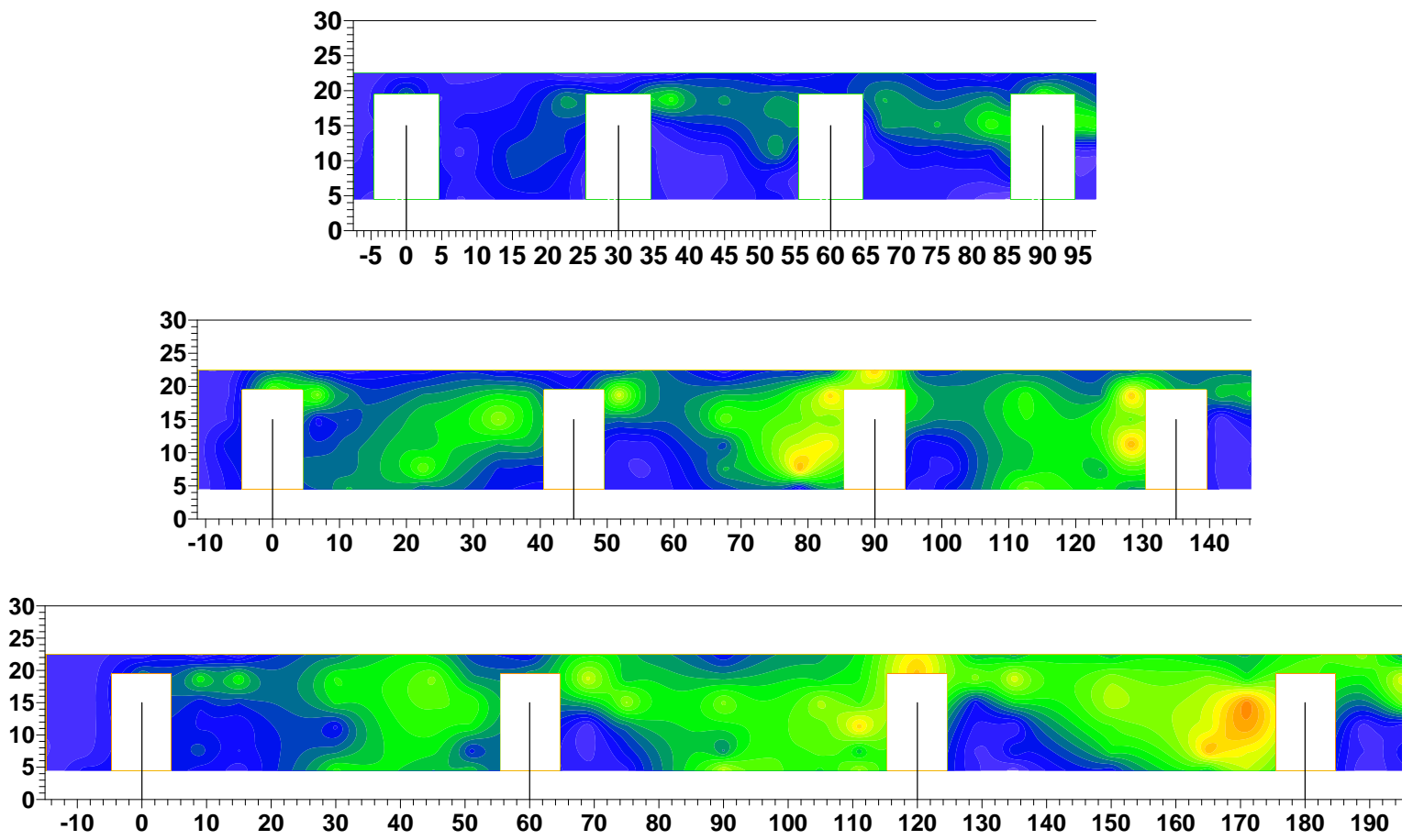

$\begin{array}{lllllllllllllll}-15 & -5 & 5 & 15 & 25 & 35 & 45 & 55 & 65 & 75 & 85 & 95 & 105 & 115 & 125\end{array}$

Figure 11. Reynolds stress $-\rho \overline{\mathrm{u}_{\mathrm{f}} \mathrm{v}_{\mathrm{f}}} / \rho u_{*}^{2}$ at $z / d=0.05$ for $s / l=2$ (top), $z / d=0.05$ for $s / l=3$ (middle), and $z / d=0.04$ for $s / l=4$ (bottom)
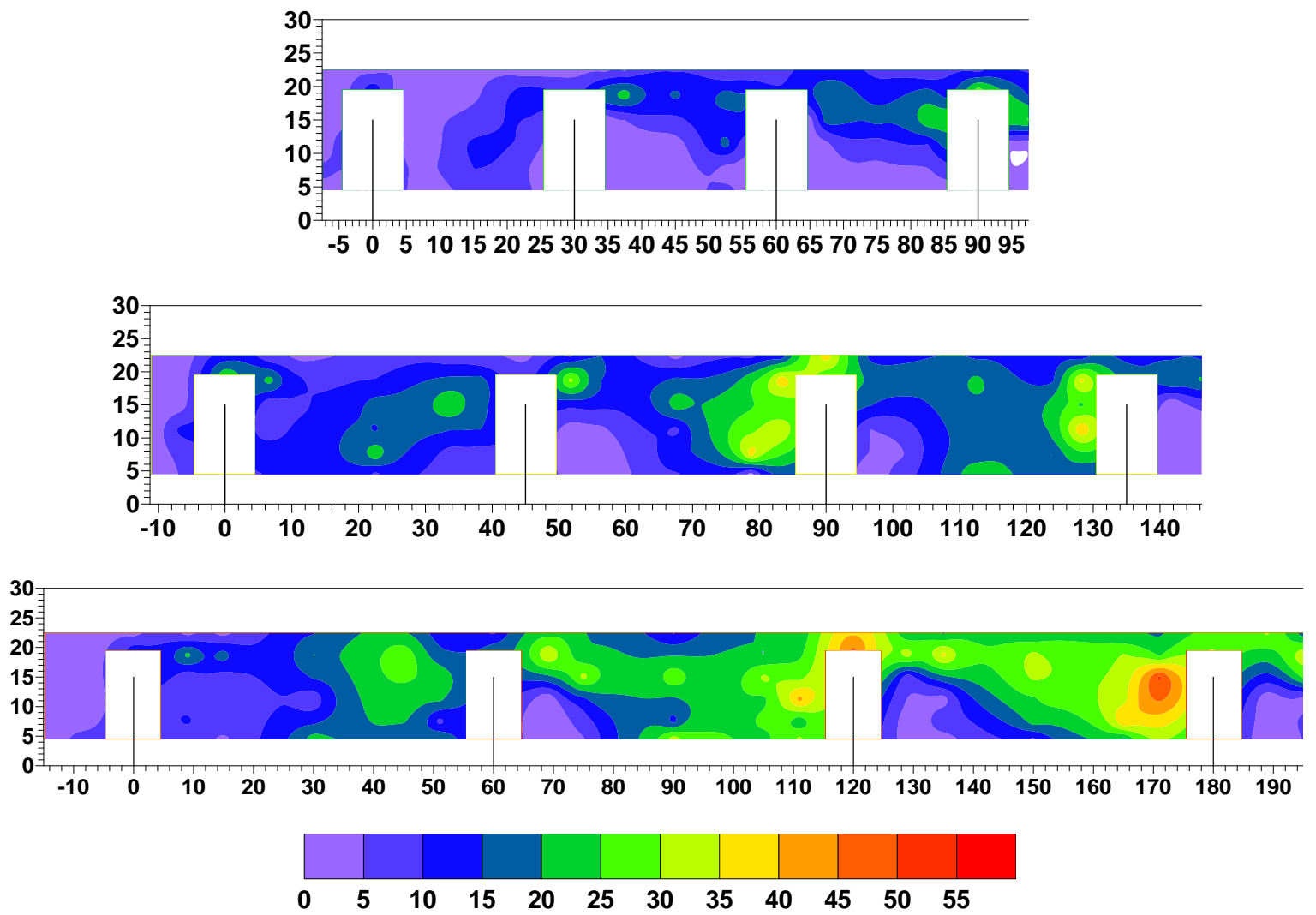

Figure 12. Bed shear stress $\tau_{b} / \tau_{b, a}$ of $s / l=2$ (top), $s / l=3$ (middle), and $s / l=4$ (bottom). 


\section{Bed shear stress $\tau_{b} / \tau_{b, a}$}

In general, Figure 12 illustrated that scenario $s / l=2$ showed the smallest value of bed shear stress value $\tau_{\mathrm{b}} / \tau_{\mathrm{b}, \mathrm{a}}$ while scenario $s / l=4$ expressed the highest value. Scenario $s / l=2$ showed that bed shear stress value $\tau_{\mathrm{b}} / \tau_{\mathrm{b}, \mathrm{a}}$ difference between primary flow region and groin field was not significant whereas $s / l=3$ and $s / l=4$ scenario expressed significant differences. Bed shear stress value $\tau_{b} / \tau_{b, a}$ tended to grow wider at downstream of each groin field. Immense bed shear stress $\tau_{b} / \tau_{b, a}$ value difference occupied second and third groin field. Scenario $s / l=2$ showed overwhelming bed shear stress $\tau_{b} / \tau_{b, a}$ value at tip of fourth groin, whereas scenario $s / l=3$ expressed similar phenomenon at third groin tip. In $s / l=4$ scenario, the high bed shear stress $\tau_{b} / \tau_{b, a}$ value located at third and fourth groin tip.

\section{Conclusion}

This work showed that Reynolds stress $-\rho \overline{\mathrm{u}_{\mathrm{f}} \mathrm{W}_{\mathrm{f}}} /$ $\rho u_{*}^{2}$ and $-\rho \overline{v_{\mathrm{f}} \mathrm{W}_{\mathrm{f}}} / \rho u_{*}^{2}$ distributions were different compared Reynolds stress $-\rho \overline{u_{f} v_{f}} / \rho u_{*}{ }^{2}$. Reynolds stress $-\rho \overline{u_{\mathrm{f}} \mathrm{W}_{\mathrm{f}}} / \rho \mathrm{u}_{*}^{2}$ and $-\rho \overline{\mathrm{v}_{\mathrm{f}} \mathrm{W}_{\mathrm{f}}} / \rho \mathrm{u}_{*}^{2} \operatorname{did}$ not show specific distribution, while Reynolds stress $-\rho \overline{\mathrm{u}_{\mathrm{f}} \mathrm{V}_{\mathrm{f}}} / \rho \mathrm{u}_{*}^{2} \quad$ reveal specific pattern. Furthermore, Reynolds stress $-\rho \overline{u_{\mathrm{f}} \mathrm{v}_{\mathrm{f}}} / \rho \mathrm{u}_{*}^{2}$ value at primary flow region was higher than Reynolds stress at groin field.

Generally, bed shear stress value for $s / l=2$ was the lowest, while bed shear stress value for $s / l=4$ was the highest. For each groin field, area containing high bed shear stress value occurred at downstream of groin field. High bed shear stress value also occurred at tip of groin.

\section{References}

Alauddin, M. \& Tsujimoto, T. (2013). Groin Configurations: An Approach towards Stable Lowland Rivers with Improved Environmental Functions. World Academy of Science, Engineering and Technology International Journal of Environmental and Ecological Engineering, $7(11)$.
Dehghani, A. A., Azamathulla, H. M., Najafi, S. A. H. \& Ayyoubzadeh, S. A. (2013). Local scouring around L-head groynes. Journal of Hydrology, $504,125-131$

Dey, S. \& Barbhuiya, A. K. (2005). Flow Field at A Vertical-wall Abutment. Journal of Hydraulic Engineering, ASCE, 131(12), 1126-1135.

Duan, J. G. (2009). Mean Flow and Turbulence around a Laboratory Spur Dike. Journal of Hydraulic Engineering, ASCE, 135(10), 803-811.

Kadota, A., Suzuki, K. \& Kojima, E. (2010). Flow Visualization of Mean and Coherent Flow Structures Around T-type and L-type Groynes. River Flow 2010.

Klingeman, P. C., Kehe, S. M., \& Owusu, Y. A. (1984). Streambank Erosion Protection and Channel Scour Manipulation Using Rockfill Dikes and Gabions. Water Resources Research Institute Report No. WRRI-98, Oregon State Univ., Corvallis, Ore.

Kuhnle, R. \& Alonso, C. (2013). Flow Near a Model Spur Dike with A Fixed Scoured Bed. International Journal of Sediment Research, 28(3), 349-357.

Kuhnle, R. A., Jia, Y. \& Alonso, C.V. (2008). Measured and Simulated Flow Near a Submerged Spur Dike. Journal of Hydraulic Engineering, ASCE, 134(7), 916-924

Muto, Y., Imamoto, H., \& Ishigaki, T. (2000). Velocity Measurements in a Rectangular Embayments Attached to a Straight Open Channel. Annuals of Disas. Prev. Res. Inst, Kyoto Univ., N43B-2.

SonTek. (2001). ADVField/Hydra Operation Manual Acoustic Doppler Velocimeter (Field) Technical Documentation. San Diego: SonTek.

SonTek. (2001). Acoustic Doppler Velocimeter (ADV) Principles of Operation Acoustic Doppler Velocimeter (Field) Technical Documentation. San Diego: SonTek. 